\title{
Beyond Knowledge and Pedagogy: Academic Optimism of Teachers in High Need Schools
}

\author{
Sheila R. Vaidya* \\ School of Education, Drexel University, Korman Center 222, Philadelphia, Pa 19104 \\ *Corresponding author: vaidyasr@drexel.edu
}

Received November 28, 2014; Revised December 11, 2014; Accepted December 18, 2014

\begin{abstract}
The question that drives the research presented in this paper is -why are some teachers in a cohort more effective than others, despite the fact that the academic preparation is the same for all? We find the answers in the teacher academic optimism- teacher beliefs and attitudes of efficacy about the students and themselves. Next, we visit their classrooms, review their journals, question them about how they use mentors. Based on this data, we present five case studies, characterize teacher beliefs and philosophy while observing how their academic optimism plays out in their classroom behavior.
\end{abstract}

Keywords: knowledge, pedagogy, high need schools

Cite This Article: Sheila R. Vaidya, "Beyond Knowledge and Pedagogy: Academic Optimism of Teachers in High Need Schools.” American Journal of Educational Research, vol. 2, no. 12 (2014): 1218-1224. doi: 10.12691/education-2-12-14.

\section{Introduction}

Teachers who work in high need urban schools are faced daily with many complex and difficult situations. Often, these teachers feel inundated by the challenges confronting them, and they leave the profession. Highpoverty, low-performing schools continually struggle to recruit and retain teachers and principals. Retention is far more difficult than recruitment. While they find it difficult to recruit experienced applicants, the staff turnover is at a much higher rate (over one in five teachers every year), and they must fill vacancies every year, sometimes with less-qualified candidates. Data from the Education trust (Haycock, 2008, p. 7) has conveyed that in high need high poverty, low performing schools, teachers are twice as likely to have less experience, lack certification and about $70 \%$ typically would be teaching out-of field.

Research supports the concept that teacher quality has a strong impact on student achievement. In her review of several studies about quality teachers, Rice (2003) summarizes teacher experience, advanced degree and certification as important factors for characterizing teachers who impact student achievement. Based on her findings, Rice (2003) concludes that investing in teachers can make a difference in student achievement. While quality preparation and experience are important in the making of a high quality teacher, we believe that additional attributes characterize a high quality teacher in a high need school. In a high needs school, teachers are called upon to teach students who pose numerous challenges. After a few encounters in a high needs classroom, many teachers want to leave. However, it is those very challenges of a high needs classroom that make some teachers want to stay. In her book What Keeps Teachers Going (Sonya Nieto (2003), engaged eight veteran teachers in an Inquiry Group over a period of one year. These were teachers who were successful with students of diverse backgrounds. Six of the eight teachers had taught in a high needs classroom for 25 years. Understanding the difficulties encountered, Nieto directs her investigation to "what keeps them going?" Studying the veteran teachers over a year, Nieto describes the love the teachers felt for the students and the hope they had for them. Nieto adds: "The teachers in my study were angry at the disrespect they were shown by the system. They were angry at the conditions in which they had to teach and in which children had to learn. They were angry at racism and inequality. They were angry with the bureaucracy. One teacher expressed anger at the mouse droppings she had to clean up every morning from the computers that didn't work. These were some of the things that they were angry about. In all the time that I spent with them, they never talked about anger at kids”.(P. 31 )

Nieto's work suggests the importance of teacher beliefs that keeps some teachers persisting in the face of continuously difficult circumstances. Such teachers are often known to have a high impact on students' lives because they act out of strong convictions about their teaching efficacy and about the students' capability as learners and achievers. Teacher self-efficacy and student capability beliefs are important because such beliefs drive teachers to persist in helping their students to learn and produce high quality teaching.

In this context, what Hargreaves (2000) describes as the "emotional arena" in education is important to consider. According to Hargreaves (2000), teaching, learning and leading are emotional practices and defined by cognitive as well as affective features. Teachers who believe that 
any or all students are capable of learning have a belief system and a positive optimism about their own ability to teach and about the student's ability to learn. In a high needs school, teacher self-efficacy and optimism about one's own capacity to teach and about the students' ability to learn should frame a teacher's thinking process so as to energize their work. There has been little inquiry into the effects on student achievement that may be associated with teacher beliefs, teacher motivation, and how these impact commitment and motivation to improving student achievement.

Teacher beliefs have long been studied in relationship to teacher knowledge and behavior in the classroom. Teachers' beliefs about the nature of learning, about learners, (Bruner, 1996) has long been known to impact their classroom practice. Research points to a strong connection between what teachers believe about their students, about themselves and how they teach (Nietfeld \& Enders, 2003). It is thought by some that teachers' beliefs might cause some teachers to be more thoughtful than others in their work, more persevering with students and therefore have a stronger influence in the classroom(Fairbanks et al., 2009). To further elaborate on this idea, we turn to the psychological construct called Academic Optimism.

\section{Academic Optimism}

Academic Optimism is a psychological construct that arose out of quantitative studies that identified three related school characteristics that had strong associations with academic achievement. Collective teacher efficacy, academic emphasis, and trust have each been linked to academic achievement, and in each case the association was so strong that it overcame the effects of socioeconomic status (McGuigan, 2005). A series of studies during the seventies and eighties referring to "school climate" have shown the positive impact of a school environment that fosters learning and academic achievement (Brookover, et. al, 1977; Anderson, 1982). Conceptualized within the frame of organizational theory work, Hoy, Tarter and Woolfolk-Hoy (2006) have stated that there are three organizational properties that seem to make a significant contribution to student achievement. These are: collective teacher beliefs -that they can teach the most difficult students, trust in students and parents and academic emphasis in the school, adding that these three properties are interconnected to support each other, resulting in a positive and optimistic climate in the school. Hoy et al., 2006 consider these to be key factors that enable schools to overcome the disadvantages of students' low socioeconomic status. This research is categorized as the "Academic optimism of schools". Taking this research further, Woolfolk-Hoy and Kurz (2006) studied academic optimism and found it to have high validity as an individual teacher variable. According to Kurz (2006) "the teacher sense of academic optimism is a self-referent positive belief about the capacity to teach all students to form trusting relationships with other students and parents and to prioritize academic tasks” (Kurz, 2006, p. 109) Based on these findings, Hoy and colleagues have stated that "academic optimism of teachers is a single latent construct that is reflective of an individual's psychological
state.”According to Purkey \& Smith (1983) and Scheerens \& Bosker (1997) the findings in the initial research on academic optimism are not only consistent with earlier research, but additionally, offer some explanation about how some of these factors influence teacher beliefs that lead to student achievement. The studies on academic optimism are particularly attractive because they emphasize the potential of schools to overcome the power of socioeconomic factors that impair student achievement (Beard, 2008).

Beard, Woolfolk-Hoy and Hoy, (2010), view academic optimism as a teacher characteristic that influences academic achievement. Thus, collective academic optimism and individual teacher optimism may be both important in influencing student academic achievement. The question we investigate in this research is: how does individual teacher academic optimism work to influence student achievement? Does individual teacher academic optimism influence academic optimism of other teachers in the school? What is the teaching like of those teachers who score high on Academic Optimism? Before going further into how I studied these questions, I present the theoretical framework into which the construct of academic optimism is embedded.

\section{Theoretical Framework}

Emanating from positive psychology and humanistic psychology (Hoy, 2006) the theoretical foundations of academic optimism are influenced by Albert Bandura's social - cognitive and self-efficacy research and Seligman's research on learned optimism (1998) as well as Hoy et al's own research on culture and school climate. The concept of optimism denotes that positive beliefs are of more value than the negative. Positive psychology is embedded in the view that the quality of our lives depends both on what we do and how we experience what we do. The theory of positive psychology (Carr, 2004) refers to psychological state as a mental state of a person. A positive state is defined as one with energized focus and motivation, while a negative one would be the lack of focus and motivation. It is important to understand a teacher's knowledge, skills and dispositions relative to student growth. Do high functioning teachers have positive beliefs about themselves, their students and the content they teach? As a result, are they more focused and motivated to achieve student learning? According to Beard (2008) factor analysis loadings on the academic optimism scale indicated the following factor loadings: Sense of efficacy 0.54 , Trust 0.81 , Academic emphasis 0.78 suggesting that the three variables form the general construct called academic optimism.

Thus, to further elaborate, Academic optimism of teachers is a construct comprising three components: teachers' sense of self-efficacy, teachers' sense of academic emphasis, and teachers' sense of trust in their students and parents (Hoy, Tarter \& Woolfolk- Hoy, 2006). Hoy et al., 2006 believed that the teacher's sense of academic optimism encompasses teachers' positive beliefs about themselves, about their students, parents and this positive energy extends to emphasizing academics for the students energized by the belief that they will succeed. Teacher efficacy is a cognitive belief, faculty trust in 
parents and students is an affective response while academic emphasis - giving the importance to academics in school is resulting teacher behavior from a sense of efficacy and trust that students will learn (Hoy, 2005). Optimism is the overwhelming theme that unites efficacy, trust and academic emphasis because each of these elements contains a sense of the possible. Optimism entails thinking about the future, it is a positive emotion, a positive force linked to perseverance and personal control known to broaden and drive the individual's cognitive and behavioral repertoire (Peterson, 2000).

Self-efficacy has been defined as a judgment of one's ability to perform a task within a specific domain (Bandura, 1997). The study of self-efficacy in education has brought to light the importance of not only considering the ability level of an individual but the individual's belief that they will succeed on a task. According to Johnson and Birkeland (2003), self-efficacy is of central importance in all of the teacher's explanations of their decisions to stay in their schools, to move or leave teaching. It was based primarily on their perception and belief of whether they were achieving success with their students. Self-efficacy has even been shown to contribute a direct effect to performance that is equivalent to general ability itself (Pajares, 1996).

The study of self-efficacy specific to teaching has uncovered an important distinction between general teaching efficacy (GTE) and personal teaching efficacy (PTE) (Gibson \& Dembo, 1984). General teaching efficacy refers to confidence in the profession as a whole to play an important role in student motivation and performance. Personal teaching efficacy refers to the teacher's personal evaluation to implement effective teaching strategies and to effect positive change in student learning. The two scales have been shown to be independent of one another on self-report measures (Gibson \& Dembo, 1984; Woolfolk \& Hoy, 1990). Woolfolk (2000) has found that PTE and GTE both rise for pre-service teachers during their preparation program and student teaching, but then drop during their first year of teaching. Woolfolk also found a correlation between level of support and self-efficacy during the first year of teaching. She argues that we need to ensure support for novice teachers over an extended period of time in order to maintain their high levels of self-efficacy.

Bandura defines self-efficacy as the belief in one's ability to succeed in a particular situation. (Bandura 1977, p. 193). The concept of self-efficacy lies at the center of Bandura's social cognitive theory. Efficacy research conveys how self-referent thought mediates the relationship between knowledge and action. How people judge their own capabilities and self-percepts of efficacy, they affect their motivation and behavior (Bandura, 1982, p. 122). People's judgments of self-efficacy also determine how much effort people will expend demonstrating perseverance in the face of obstacles, exerting higher levels of effort.

Teacher efficacy has been identified as one of the teacher characteristics related to student achievement. Wolfolk -Hoy (2006) defines a teacher's sense of efficacy as a "judgment of his or her capability to bring about desired outcomes of student engagement and learning, even among those who may be difficult or unmotivated" (p. 783) Thus, related to a sense of optimism about themselves and their ability to impact change, selfefficacy would be construed to be a human strength and has been shown to be related to Life Orientation optimism.

In studies of high- efficacy and low-efficacy elementary school teachers, preliminary data from classroom observations have indicated that there are important behavioral differences between these teachers, differences that yield variation in student achievement (Gibson and Dembo, 1985); These behaviors involve classroom organization, instruction and teacher feedback provided to students who are experiencing difficulty. Data on the classroom behavior of high efficacy teachers from elementary school through middle and high school reflect a strong academic orientation in a supportive classroom environment. Gibson and Dembo (1985) further report that high efficacy teachers are not as likely as low efficacy teachers to appear angered or threatened by the misbehavior of students.

Academic optimism, at both the school and individual levels, includes cognitive, affective, and behavioral components of optimism merging into a single integrated construct. (Woolfolk-Hoy, Hoy and Kurz, 2008). According to Kurz (2006), all three elements of academic optimism interact and support one another. It would thus seem plausible that to be successful in high need schools, teachers would have to persevere in the face of difficult circumstances and the successful teachers notably do.

\section{The Importance of Academic Optimism in Teacher Preparation}

For the last ten years, I have been directing a program in partnership with the School District of Philadelphia and the School of Education at Drexel University for preparing quality mathematics and science teachers for high need schools. Founded and funded by the National Science Foundation, the Robert Noyce Scholarship program provides the means to enhance our preparation by providing scholarship as an incentive to teach in high need schools. It also provides mentoring and induction support for mathematics and science teachers. To this date about twenty teachers have been placed in high need schools and some more teachers are in the preparation pipeline. Of these teachers, we found six to eight teachers to distinguish themselves as outstanding. These teachers stood out because while many teachers talked about the difficulties of teaching in high need schools, these teachers designed innovations, won awards for outstanding teaching, engaged students. Some of the students in their classes excelled and most improved over time. Their school principal and other supervisors valued them enormously. They had won awards and commendations in their schools. The question that I was always faced with is, what is it about these teachers that makes them outstanding? There was an "additional factor" about these teachers that deserved to be understood since we want to develop more such teachers. Classroom observations and interviews with these teachers led me to conclude that these teachers were different primarily in two ways- They had strong positive beliefs about themselves and about their students. They assumed that their students would be successful and that they would be 
able to teach them effectively. This was their defining characteristic.

In this context, the view that the way to improve education is to teach "best practices" to teachers did not seem to be relevant. Instead it made me think that a teacher's belief system drove innovation and practice. This observation led to the investigation of the following questions:

1. How do the high-performance teachers rank on the Academic Optimism scale?

2. How does their teaching, journal reflections, work with mentors compare with their academic optimism?

Design:

To conduct our inquiry, we used a mixed methods design following quantitative data on the Academic Optimism scale with qualitative data from teacher's interviews, Principal's reports, Classroom Observation of their teaching and teacher's journal reflections. This qualitative data combined with the quantitative data on the Academic Optimism scale allowed us to compile each teacher's profile with reference to their score on the Academic Optimism scale with qualitative data from observations, interviews and journals. Our goal was to determine the degree of consonance represented in their classroom behavior and in their thinking that would be considered as behavior of teachers who are high on academic optimism.

\section{Data Sources}

\section{i. Academic Optimism Scale:}

The Academic Optimism scale used was the Individual Teacher Academic Optimism scale, Beard and Hoy (2009). The measurement of academic optimism at the individual level is comprised of three parts. These are: teacher sense of self-efficacy, then teacher trust in students and parents, and finally, the teacher's academic press for achievement. An index of teacher sense of academic optimism is obtained by combining the measures of these three components of academic optimism, Beard, Hoy, \& Woolfolk Hoy, (2009).

\section{ii. School Principal's report}

School Principals were asked to rate each teacher in one of the four categories: Highly Effective, Effective, Developing Effectiveness, Not effective. Because the overarching goal of the Robert Noyce program is to improve student achievement and learning in high need schools, effectiveness was defined as a teacher's ability to impact student learning.

\section{iv. Teacher Journals}

Teachers were instructed to maintain journals about their teaching. We sought to understand how the teachers experienced their work across various situations. The following general guidelines were given to them:

Write in your journals about your teaching. Write about your thoughts, reflections, that pertain to issues such as preparing a lesson, what you know about your students, your beliefs about teaching, learning, how you evaluate student learning, any highlights. You could focus on any one of these issues that interest you the most and write about it.

v. How Mentoring was used:
Teachers were asked to write about their relationships with their mentors and also asked to respond to mentoring questions. We asked them how they used mentoring in their teaching and what they sought from the assigned mentor.

\section{Data Analysis}

Below we describe highlights from our data based on scores on the Academic Optimism Scale, classroom observations, teacher journals and interviews. For each teacher, we want to present how the teacher's vision and sense of academic optimism were realized by a strong sense of efficacy, trust in their students and parents resulting in classrooms that are student centered and an increased emphasis on academic achievement for all.

iii. Classroom Observations:

Classroom observations consisted of observing the conduct of a lesson on the subject area of each teacher.

\section{CarlJohnson ${ }^{1}$, Physics Teacher}

Mr. Johnson ( $\mathrm{J}$ ) is a young Physics teacher. He is currently in his third year of teaching, but was distinguished as an outstanding teacher by his Principal in his first year of his teaching. We visited his class, to observe an eleventh grade Physics lesson in a high need Philadelphia school when he was teaching the concept of sound with a music lesson and his guitar. The lesson was titled: "Physics of sound". Mr. J came to class with his guitar and explained how in musical instruments, the source of sounds is set into vibration by striking, plucking or bowing. In a violin or guitar, shortening the string results in a higher pitch. When you hang weights on the end of the string that increases the pitch too. As the string tension increases, the pitch of the sound also increases. The string producing the pitch is actually setting up a standing wave between its endpoints. The length of the string determines the wavelength of this standing wave. The higher the pitch, the higher the frequency. The speed of the wave is equal to its frequency multiplied by its wavelength. Mr. J scaffolds student learning and inspires their interest in learning the physics of sound. Next, each student who is asked to build their own instrument has to write a paragraph about how pitch is affected.

In this way, Mr. J engages the entire class some experimenting on the varying pitch with two glasses of water while he varies the length, tightness of his guitar string and asks a student to read the sound frequency (pitch) on a chromatic tuner.. The Principal comes to meet us, telling us that the Physics laboratory was specifically designed for Mr. J. and adds "we love him and the students do too".

\section{Excerpts from Journal Entries:}

More concretely, it is the foundation of my approach to lesson planning and classroom discipline. If I have had any success as an educator thus far, in my very young career, I would most likely attribute it to my humility and honesty as a person in the classroom. I feel that if I respect the students enough to be honest with them, then they will be on board with any plans I might make.

This brings up another basic tenet of my philosophy as a teacher: follow up and follow through. Students and 
teachers engage in a profound relationship, and like all relationships, it is defined with trust and communication. I believe that we as teachers must say what we will do and then do what we said. I myself am certainly not perfect on this count. If I get a student to open up on their dossier, and then cannot use that information to make the class more relevant to them, they will rightly come to think of the time they spent filling it out as wasted time.

How Mentoring was used:

Mr. Johnson defined his relationships with two mentors as an intellectual relationship connected with developing additional learning experiences that are helpful for personal learning as well as for developing additional proficiency.

\section{Summary profile:}

It can be concluded based on the journal excerpts, the observations, use of mentors that Mr. Johnson's classroom behavior represents hard work and creativity in the teaching of the unit on the Physics of Sound- he made the lesson relevant to students through the music he knows they care about. His journal reflections convey respect for the students and a strong belief that they can succeed. His mentoring relationship conveys an emphasis on developing stronger intellectual connections and proficiency as a teacher. He uses reflections on his own learning process as a way of stimulating reflections on preparation for the profession of teaching.

Case \#2: Daniel Thompson, Physics and Mathematics teacher

Mr. Thompson teaches Physics and Mathematics in a high need urban charter school. He is a very dynamic teacher. In his first year of teaching he has received three awards. His class presents interested and motivated students influenced with the high energy of the teacher who is driving them to learn. Mr. Thompson enacts a wide range of instructional strategies combining technology including interactive power points and hands-on resources to provide students with varied learning styles to expand learning opportunities for different learners. Mr. Thompson has indicated that he likes to keep challenging himself. His teaching style reflects a characteristic playfulness, (cartoons on power point slides) relating to students' backgrounds by describing the physics of Michael Jackson's moonwalk.

Mr. Thompson's awards say:

Coming to school each day giving your students $150 \%$ and being the best teacher ever.

Initiative and continuous improvement Commitment to Excellence and "calm" presence.

Dynamic teacher.

\section{Excerpts from Journal Entries:}

The main thing that I took away from this portion of the conversation was accountability and the importance of keeping each and every student attentive throughout the lesson. Strategies that Mrs. Cooper discussed with me included: Having very low SPED students do tasks that aren't always responding (such as reading a problem), coming back to the student at a later point - giving them time to find the answer, coming back to the student after a different student answers a similar problem, and guiding the student step by step through the solution to the question being asked.
How Mentoring was Used: I used several mentors to help me teach and perfect teaching in several different topics.

Summary Profile: Mr. Thompson's profile presents ambitious teaching and the desire to pay attention to every individual student in the class and their academic achievement. He uses mentoring to perfect those aspects of his teaching that he himself sees as needing adjustment. He uses technology in a playful manner, reminding students that learning is fun.

Case \#3: Penelope Christ, Mathematics Teacher

Ms. Christ is a career changer. She has a background in systems engineering and computer programming. She worked for several years as a systems engineer for a major corporation and then obtained certification in mathematics. We observed her teaching a fifth grade class in a Charter school in Philadelphia. Her self-efficacy is conveyed in several statements such as "I know I can get all students to learn”. Soon after she started teaching at the Charter school, she was given the job of a "Mathematics Facilitator" at the school which enabled her to change the achievement of the entire school. She used systems approach strategies to turn around the school's mathematics performance using a new curriculum which emphasized mathematics basics, and prerequisite skills; she had school competitions to motivate student learning.

\section{Excerpt from Journal Entries:}

This write-up is about my journey as a mathematics facilitator in a high needs K-8 charter school in Philadelphia, from August 2006 until July 2009. In the fall of 2006, when I first started at the school, I found the K-8 mathematics achievement scores according to the state assessment (Pennsylvania State Standards Assessment or PSSA) to be quite low (only 32\% of the students scored at the Proficient level or above). I launched a program for mathematics achievement that included several components, such as curriculum and instructional redesign, the increasing of student and teacher motivation, and seeking support from the school leadership. There was an overall increase in the mathematics proficiency. In June 2009, 75\% of the students scored Proficient or above, which represented a $134 \%$ increase. Here I tell the story of a school transformation as the school's self-image began to change with increasing student achievement and how the school was able to sustain its new status.

How Mentoring was Used: Ms.Christ had the good fortune of having chosen a highly effective mentor, a former school principal who used strategic mentoring to enable Penelope to improve student achievement and learning.

Summary Profile: Penelope described how her experience as a systems engineer in industry helped her to focus on all the key variables and the dynamic complexity of the relationships among them. She states: In this whole system, we consider the effects of interventions over time. We are able to see patterns more clearly and to understand how to change them. For example, systems thinking enables us to see the problems with the medical model and points to interventions that can break the cycle of dependence as well as strengthen classroom instruction. Thinking about the complex, dynamic relationships in a whole system helps us to see where to make changes that can lead to significant, enduring improvements.

Case \# 4: Andrew Weil 
Andrew Weil is a mathematics teacher in an All Boys high needs school in North Philadelphia. He has a degree in Engineering, but chose to go into teaching mathematics. This is his third year of teaching. He visits parents at their homes when his students do not show up in the classroom and has found this to be a positive way of creating an effective classroom environment.

A mathematics lesson in measurement was taught by visiting a littered empty lot and determining how it could be transformed into a playground. Enlisting the supervision help of two students, Andrew organized his class into teams. He then took the class to the lot to $\mathrm{m}$ measure its dimensions, and sketch topographical features. The students then returned to the class, designed and located play equipment, paths, perimeter fencing. They looked up costs, made phone calls and prepared a budget.

\section{Journal Excerpts:}

I had heard horror stories about inner-city schools where the adults are the ones who create the most problems. I started making home visits. This opened up a whole new perspective. It was one thing to have Michael Landers in my class. But meeting his grand-mother (with whom he lived) and being in his house made you understand that you have got to help Michael come to school and learn. "I want the students to be engaged, to learn. They can do it. I use different methods to keep students interested. Often, I use math games to keep the students involved.

Summary Profile: Andrew Weil uses his outgoing personality to visit parents and is able to forge strong relationships and partnerships with parents. He demonstrates that a chat in a living room can help cement and develop a key relationships that fosters learning in his classroom.

\section{Case \# 5: Kathleen Turner}

Kathleen Turner is a second year ninth grade biology teacher in a Philadelphia high need school. Her school principal has indicated that she is an outstanding and creative teacher and has commanded the respect of her students. She does not have any problems with the management of her classroom because the students know she cares deeply about their learning and their future. The school has minimal resources so Kathleen applied for a Science Teacher's grant to buy dissection kits to teach anatomy to her students. She received the grant which helped her buy Dissection kits for her class. The students dissected a frog, a rat and a fetal pig.

She told us that hands-on dissection helps students understand the internal organs functions and relationships to one another. They also learn that all organs are connected and each system is inter connected through veins and arteries.

\section{Journal Excerpts:}

I find a great deal of personal satisfaction in imparting knowledge to others. I am patient, I am dedicated to the progress of those I teach and keep focused on the ultimate educational goal. Nothing is more important, to an individual's happiness and well-being than learning. Learning opens up doors otherwise closed. I recognize and respect the impact a teacher can have on a student's life. A person's education reverberates down through all the years of one's life.

I think that teaching should not be mechanical, routine. I plan learning activities that will make students curious and enjoyable and not always a learning objective. When it comes to learning, attitude is very important.

\section{Summary Profile}

Kathleen has given a great deal of thought to what teaching means. She did not request a mentor and said that she was prepared for the challenges of a class; would request a mentor if she needed one.

\section{Conclusions and Significance}

All the teachers that we profile here as gifted and as scoring high in academic optimism present certain common teacher behaviors. There is a consistent pattern in the teacher's behavior to design lessons to which students can make a meaningful connection and the willingness to take the time and put in the effort to create such instruction. All these teachers demonstrate in their teaching behavior that all students can learn if the teaching strategies are good and meaningful. Each one innovates a strategy that they see as suitable to their subject content and to the student learners, thus enacting their belief system in consonance with their academic optimism.

1. When students in a school achieve, the school's selfimage changes from a low achieving to a high achieving school. Such a turnaround is important in creating a reformed and positive culture of academic optimism and achievement. The understanding of what teachers believe and their levels of academic optimism is important knowledge for teacher educators as we develop preservice programs that will prepare competent teachers prepared to equitably meet the ever changing needs of students. Using the constructive developmental theory of adult learning as a frame of reference, Berger (2002) argues that preservice teacher education programs should develop teacher's complexity of thinking and support teacher development in this way. Reiman (1999) who also looks for improving teacher preparation recommends reflective practice in teaching to avoid practitioners running the risk of relying on routinized teaching.

2. While attributing these differences to factors such as teacher beliefs, vision, identity and belonging- they tie all these factors to the core called self-knowledge and how teacher education programs can increase several opportunities for attaining this self-knowledge, Fairbanks et al. (2010). Using Robert Kegan's (1982, 1994) theory of adult development as a frame of reference for teacher development, we can infer that the evolution of the self is signified in the way humans change and grow over the course of their adult lives, as life experiences many of which are transformative in quality help develop the complexity of one's thinking. This changes teacher thinking over time. Teachers who may not be able to deal with certain complex situations as young adults may grow in complexity over time and increase the transformative nature of meaning making for their students. Thus, an emphasis on change and personal and social developmental maturity are areas of self-knowledge that may enable teachers to have a focused vision of teaching.

3. The application of the theory of academic optimism conveys a positive attribution to schools, teachers, students- and a sense that learning can improve, schools can become outstanding, teachers and students can grow further and obstacles can be overcome. This thinking 
should be the beginning and mainstay of any learning environment.

4. Woolfolk Hoy and her colleagues (2008) were first to investigate individual teacher sense of academic optimism as a self-referent belief about the capacity and confidence to teach all students, to form trusting relationships with teachers and parents and to emphasize academic tasks. While it is important to cultivate such self-referent positive beliefs among the teaches that we educate, it is also necessary to link teacher optimism to student learning and study this relationship in future research.

5. Teacher Optimism can be cultivated by emphasizing strong preparation of content knowledge, pedagogical knowledge and technology knowledge. Competence results in a sense of confidence or self-efficacy. Next, positive teaching experience and a mind-set that values teaching instills in a teacher the thinking that they "can" teach well and can teach all students. This is the core principle (Woolfolk, 2000) of developing a sense of positive academic optimism.

\section{References}

[1] Anderson, C. 1982. The search for school climate: a review of the research. Review of Educational Research 52: 368-420.

[2] Bandura, A. 1977. Self-efficacy: Toward a unifying theory of behavior change. Psychological Review 84: 191-215.

[3] Bandura, A. 1982. Self-efficacy mechanism in human agency. American Psychologist 37, no. 2, 122-147.

[4] Beard, K. S., Hoy, W. K., \&Hoy, A. W. 2010. Academic optimism of individual teachers: Confirming a new construct. Teaching and Teacher Education 26, no. 5: 1136-1147.

[5] Berger, J.G. 2002. Exploring the connection between teacher education practice and adult development theory. Unpublished Doctoral Dissertation.

[6] Brookover, W., Beady, C., Flood, P., Schweitzer, J. \& Wisenbaker, J. 1977. Schools can makea difference. Washington, DC: National Institute of Education. (ERIC Document Reproduction Service No ED 145 034)

[7] Brophy, J. E., \& Good, T. L. (1970). Teachers' communication of differential expectations for children's classroom performance: Some behavioral data. Journal of Educational Psychology 61, 365-374.

[8] Bruner, J. 1996. The culture of education. Cambridge, MA: Harvard University Press.

[9] Cohen, J. 2001. Social and emotional education: Core principles and practices. In J. Cohen (Ed.), Caring classrooms/intelligent schools: The social emotional education of young children. New York: Teachers College Press.

[10] Cohen, J. 2006. Social, emotional, ethical and academic education: Creating a climate for learning, participation in democracy and well-being. Harvard Educational Review 76, no. 2: 201-237.

[11] Carr, A. 2004. Positive Psychology: The science of happiness and human strengths. New York: Routledge.

[12] Csikszentmihalyi, M. 1997. Finding Flow: The Psychology of Engagement with Everyday Life. New York: Harper-Collins.

[13] Darling-Hammond, L. and Bransford,J. 2005. (Eds.), Preparing Teachers for a Changing World: What Teachers Should Learn and Be Able to Do. Jossey-Bass Wiley: San Francisco.
[14] Davis, H.A. 2003. Conceptualizing the role and influence of student-teacher relationships on children's social and cognitive development. Educational Psychologist 38, no. 4: 207-234.

[15] Dembo,M.H; \& Gibson,S. 1985. Teacher's sense of Efficacy: An important factor in school improvement. The Elementary School Journal 86, no. 2: 173-184.

[16] Edmonds, R. 1979. Effective Schools for the Urban Poor. Educational Leadership, 37, no. 1: 15-23.

[17] Fairbanks,C.M; Duffy,G.G; Faircloth, B.S; He,Ye; Levin,B; Rohr, J; \& Stein, C. 2010. Beyond Knowledge: Exploring Why Some Teachers are More Thoughtfully Adaptive Than Others. Journal of Teacher Education 61, no. 1-2: 161-171.

[18] Gibson, S., \& Dembo, M. 1984. Teacher efficacy: A construct validation. Journal of Educational Psychology 76, 569-582.

[19] Greenwald, R., Hedges, L., \& Laine, R. 1996. The effect of school resources on student achievement. Review of Educational Research, 66, no. 3: 361-396.

[20] Haycock, K.P. 2002. Toward a Fair Distribution of Teacher Talent. Educational Leadership, 60, no. 4: 11-15.

[21] Haycock, K.P. 2008. t's Up to Us: Going the Distance to Close Gaps and Raise Achievement for All. Opening Plenary Session, Educational Trust National Conference.

[22] Haycock, K.P. 2009 Secrets of High Achieving Schools in High Poverty Areas. School Leadership Briefing. http://www.schoolbriefing.com/922/secret

[23] Hoy, W. K., Tarter, C. J., \& Woolfolk Hoy, A. 2006. Academic optimism of schools: A force for student achievement. American Educational Research Journal, 43 no. 3 425-446.

[24] Kurz, N. M. 2006. The relationship between teachers' sense of academic optimism and commitment to the profession. The Ohio State University). ProQuest Dissertations and Theses, 154 p. Retrieved http://search.proquest.com/docview/305294758?accountid=10559

[25] Nietfeld, J. L., \& Enders, C. K. (2003, March 17). An examination of student teacher beliefs: Interrelationships between hope, selfefficacy, goal-orientations, and beliefs about learning. Current Issues in Education [On-line], 6 (5). Available: http://cie.ed.asu.edu/volume6/number5/

[26] Nieto, S. 2003. What Keeps Teachers Going? New York: Teachers College Press.

[27] Peterson, C. (2000) The Future of Optimism. American Psychologist 55: no. 1: 44-55.

[28] Rice, J.K. 2003. Teacher Quality: Understanding the Effectiveness of Teacher Attributes. Economic Policy Institute, Washington, DC.

[29] Richardson, V. (1996).The role of attitudes and beliefs in learning to teach. In J. Sikula (Ed.), Handbook of research on teacher education (2nd ed., pp. 102-119). New York: Macmillan.

[30] Seligman,M. 1998. Learned Optimism: How to change your mind and your life. New York: Pocket Books.

[31] Seligman, M., \& Csikszentmihalyi, M. 2000. Positive Psychology: An Introduction. American Psychologist 55, no. 1: 5-14.

[32] Seligman, M. 2002. Positive psychology, positive prevention, and positive therapy. In C. Snyder \& S. Lopez (Eds). Handbook of positive psychology. New York: Oxford.

[33] Seligman,M. 2006. Learned Optimism: How to change your mind and your life. New York: Pocket Books.

[34] Woolfolk, A., \& Hoy, W.K. 1990 Prospective teachers' sense of efficacy and beliefs about control. Journal of Educational Psychology 82, 81-91.

[35] Woolfolk-Hoy 2000. Changes in Teacher Efficacy during the early years of teaching. Paper presented at the annual meeting of the American Educational Research Association, New Orleans, LA.

[36] Woolfolk Hoy, A., Hoy, W. K., Kurz, N. (2008). Teacher's academic optimism: the development and test of a new construct. Teaching and Teacher Education 24, 821-834. 